\title{
Titanium Biomimetically Coated With Hydroxyapatite, Silver Nitrate and Polycaprolactone, for Use In Biomaterials (Biomedicine)
}

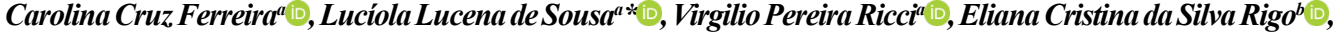 \\ Alfeu Saraiva Ramos ${ }^{a}$, Maria Gabriela Nogueira Campos $^{a}{ }^{\oplus}$, Neide Aparecida Mariano ${ }^{a} \oplus$. \\ ${ }^{a}$ Instituto de Ciência e Tecnologia, Universidade Federal de Alfenas - UNIFAL, \\ Rodovia José Aurélio Vilela, 11.999, Cidade Universitária, CEP 37715-400, Poços de Caldas, MG, Brasil. \\ ${ }^{b}$ Departamento de Ciências Básicas, Faculdade de Zootecnia e Engenharia de Alimentos, Universidade de \\ São Paulo - USP, Rua Duque de Caxias, 225, Jardim Elite, CEP 13635-900, Pirassununga, SP, Brasil.
}

Received: February 22, 2019; Revised: August 27, 2019; Accepted: November 02, 2019.

\begin{abstract}
Titanium is used in orthopedic and orthodontic implants because it has good corrosion resistance and excellent biocompatibility. Thus, studies seek to obtain a coating to improve the adhesion between the bone and the implant, by modifying the metal's surface. The objective of this work was to biomimetically coat C.P. Ti with hydroxyapatite doped with silver nitrate, a component with antimicrobial properties, coating the metallic-ceramic composite with a polycaprolactone polymer film, which is known by generate improved implant-tissue interaction, and reducing postoperative complications from bacterial infections. The characterization of the material demonstrated the existence of the coating overall surface of the metallic substrate. The results obtained from the bacterial culture tests with Staphylococcus aureus showed that nitrate was effective in reducing the amount of live bacteria present in the supernatant, as well as those adhered to the surface of the material. In addition, the polymeric coating did not prevent the release of the bactericidal agent, not interfering in the effect there.
\end{abstract}

Keywords: Titanium, hydroxyapatite, polycaprolactone, biomimetic coating.

\section{Introduction}

Alterations in the functioning of cells, tissues or organs (degenerative diseases), inflammations affect millions of people around the world. With this motivation, the search for new technologies that aim to improve and optimize products and processes is becoming progressively constant. The search for materials that allow the substitution of tissue and bones has increased significantly in the last few years ${ }^{1-4}$.

Studies on the application of biomaterials of natural or synthetic origin have been gaining more space in biomedicine, as they allow the substitution or improvement of tissues, organs and body functions $s^{5,6}$.

The search for functional materials has increased significantly in the last few years, and commercially pure titanium (C.P. Ti) and its alloys have broad application in this area because of their high degree of resistance to corrosion in bodily fluids, as well as their low modulus of elasticity and characteristics as biocompatible materials $\mathrm{s}^{4,7-9}$.

With the intention of promoting and accelerating osseointegration, reducing possible post-surgical damage and, consequently, accelerating patient recovery, a coating of hydroxyapatite (HA), the principal component of bones, is necessary on the metallic implant. This coating facilitates the chemical bonding between the live tissue and the implanted material, as it is a bioactive substance ${ }^{10,11}$.
As a surgical procedure, some bacterial infections can occur, resulting in recurring surgical interventions on the patient. In this sense, studies are being developed for the application of bactericidal agents on the surfaces of the materials to be implanted. Silver nitrate $\left(\mathrm{AgNO}_{3}\right)$ has been used for this purpose, since silver can cause the disruption of bacterial cell membranes ${ }^{12}$. Polycaprolactone (PCL) is a synthetic polymeric material, known by its biocompatibility and biodegradability, used also as a biological agent. In addition, PCL has the capacity to form films on metallic and ceramic surfaces ${ }^{13,14}$

Despite all caution, surgical procedures for implants involve risks of infection associated with the contamination of the implant itself and/or the conditions of the patient and the surgery. Thus, bacterial infection and the formation of biofilms are the main causes of post-surgical complications regarding implants, followed by rejection reactions. The formation of a biofilm corresponds to the bacterial adhesion on a surface which can be of biotic (animal or plant tissue) or abiotic (metals, polymers) origin. This is considered a factor in $80 \%$ of the cases of infections associated with biomedical implants. As such, an analysis of this parameter in necessary during the development of a new biomaterial ${ }^{15}$.

In the literature, studies conducted by Smith show that PCL coatings on artificial titanium prostheses are possible, since the material presents good adhesion to the metallic matrix ${ }^{16}$. 
Shoja and collaborators demonstrated in their studies that silver nitrate has antimicrobial properties which also guarantees the controlled release of silver ions $\left(\mathrm{Ag}^{+}\right)^{13}$.

The effect of corrosion on the implants is another determining factor in the choice of the material that will be applied, since the release of ions in the body can be very harmful to the health of the implanted patient. In addition, corrosion may cause problems such as excessive wear of the implant, requiring replacement before the scheduled time, besides the annulment of implant efficiency resulting in loss of implant material ${ }^{17}$.

The objective of this work was the study of the attainment and characterization of C.P. Ti (grade 4) coated with hydroxyapatite doped with silver nitrate and later coated with PCL, for potential use in implants. And, afterwards, the evaluation of the bacterial viability, the formation of biofilms and the corrosion behavior in an electrolytic solution of Simulated Body Fluid (SBF).

\section{Materials and Methods}

Commercially pure titanium (C.P. Ti) discs, grade 4, with chemical composition according to ASTM F67-06 ${ }^{18}$ was used as a metallic substrate for study. In total, ten samples were used for each coating condition: one sample for characterization (Scanning Electron Microscopy (SEM), Energy Dispersive X-ray (EDX), X-ray Diffractometry (XRD) and Fourier Transform Infrared (FTIR)), three samples for corrosion tests, three samples to evaluate bacterial viability and three samples for formation of biofilms.

For surface preparation, C.P. Ti discs were subjected to 180 mesh wet-grounded sandpaper, followed by an ultrasonic bath with detergent, distilled water and isopropyl alcohol. Subsequently, the samples were immersed in a $5 \mathrm{M} \mathrm{NaOH}$ solution and placed in an oven at $60{ }^{\circ} \mathrm{C}$ for 24 hours, a step defined as alkaline treatment. Posteriorly, the discs were submitted to thermal treatment at $600{ }^{\circ} \mathrm{C}$ for 1 hour, and cooled to room temperature.

The coating with hydroxyapatite was performed by the biomimetic method, which occurs in two stages: nucleation and growth. In the first step, alkaline-treated C.P. Ti discs were immersed in a $0.002 \mathrm{M}$ solution of sodium silicate $(\mathrm{pH}=7.4)$ for seven days in an oven at $36.5^{\circ} \mathrm{C}$. In the second step, the samples were immersed in SBF solution, with a concentration of $1.5^{19}$, for seven days in an oven at $36.5^{\circ} \mathrm{C}$, changing the solution each 48 hours, to ensure the supersaturation of the environment, favoring the formation of the hydroxyapatite layer. Subsequently, the samples were washed with deionized water, dried at room temperature and left in a desiccator.

After biomimetic coating, samples were submerged in 50 $\mathrm{mL}$ of a solution of $10 \mathrm{ppm}$ of $\mathrm{AgNO}_{3}$ and kept in an oven at $37{ }^{\circ} \mathrm{C}$ for 48 hours, then dried to room temperature in a desiccator. These samples were named C.P. Ti+HA $+\mathrm{AgNO}_{3}$.
For the polymeric coating, PCL (MM 70000-90000, density $1145 \mathrm{~g} / \mathrm{mL}$ at $25^{\circ} \mathrm{C}$, Sigma Aldrich, USA) was used. The solution was prepared from the dissolution of PCL in chloroform in the ratio 1:100 (m/v). C.P. Ti samples, coated with $\mathrm{HA}$ and doped with $\mathrm{AgNO}_{3}$, were immersed in the polymeric solution for 10 seconds, and then dried at room temperature in a desiccator. These samples were named C.P. $\mathrm{Ti}+\mathrm{HA}+\mathrm{AgNO}_{3}+\mathrm{PCL}$.

Scanning Electron Microscopy micrographs of the samples were obtained in a FEI microscope, model Inspect 550, coupled to an EDX detector of the brand EDAX, model Apollo X. X-ray diffraction analysis (XRD) was performed in a Rigaku Diffractometer, model Ultima IV, with $\mathrm{Cu} \mathrm{K} \alpha$ radiation. The samples were analyzed in a $2 \theta$ range from $10^{\circ}$ to $90^{\circ}$, with step of $2^{\circ}$ per minute.

Fourier Transform Infrared analysis was performed using an Attenuated Total Reflection (ATR) accessory, in a Perkin Elmer, model Spectrum 100 FTIR Spectrometer. The samples were analyzed from 500 to $4000 \mathrm{~cm}^{-1}$ in order to identify the characteristic functional groups present.

The corrosion tests were carried in triplicate using three samples for each coating condition out by the potentiodynamic polarization technique, and were performed using an electrochemical cell, working electrode, platinum counter electrode and the saturated calomel reference electrode (SCE). The electrolytic solution was $1.5 \mathrm{SBF}$ at $\mathrm{pH} 7.4$ and $36.5^{\circ} \mathrm{C}$. The polarization curves were obtained by a continuous scanning rate of $1 \mathrm{mV} \cdot \mathrm{s}^{-1}$.

The bacterial viability tests and biofilm formation were performed in triplicate (using three samples for each coating condition). A bacterial culture test was performed using Staphylococcus aureus, with polyethylene (PE) plate as the control substrate. The titanium samples were placed on a 24-well Elisa plate, with the addition of $1000 \mu \mathrm{L}$ of Luria-Bertani medium in each well along with $5 \mu \mathrm{L}$ of the bacterial culture. The samples were incubated for 24 hours, and after this period, the supernatant was removed and transferred to another 24-well Elisa plate. To verify the amount of bacteria present in the medium, the Spectra Count ${ }^{\mathrm{TM}}$ Packard spectrophotometer was used at $570 \mathrm{~nm}$.

The plates were then washed twice with PBS and dried at $65{ }^{\circ} \mathrm{C}$ for 1 hour. They were cooled to room temperature and stained with $500 \mu \mathrm{L}$ of $1 \%$ crystal violet for 10 minutes. The dye was removed from the plates, which were then washed twice with PBS and dried overnight. The biofilms formed were dissolved by adding $95 \%$ ethanol $(500 \mu \mathrm{L})$ to each well and shaking for 2 hours. The contents were diluted 20 times and then the absorbance was recorded at $570 \mathrm{~nm}$. For comparative purposes, a C.P. Ti sample coated only with hydroxyapatite (Ti+HA) was included in this bacterial analysis. 


\section{Results and Discussion}

\subsection{Microstructural Characterization}

Figure 1a show the micrographs of the $\mathrm{Ti}+\mathrm{HA}+\mathrm{AgNO}_{3}$ obtained by SEM, demonstrating that the coating with hydroxyapatite occurred, besides the observation of agglomerates $(\mathrm{HA}+\mathrm{Ag})$, heterogeneously distributed on the surface of the samples. Similar results were obtained by Eraković $(2013)^{20}$ and Ciobanu (2011) ${ }^{21}$.

Figure $1 \mathrm{~b}$ shows the detail of the agglomerate of $\mathrm{HA}+\mathrm{Ag}$. There was the presence of metallic silver $(\mathrm{Ag})$ in a denser network of the hydroxyapatite layer. The hydroxyapatite structure possesses $\mathrm{Ca}^{+}$ions that can be substituted by metallic cations $\left(\mathrm{Ag}^{+}, \mathrm{Cu}^{2+}, \mathrm{Zn}^{2+}\right)$ of the bactericides.
These substitutions alter characteristics such as texture and crystallinity of the surface layer ${ }^{22-24}$.

However, in this work the possibility of $\mathrm{Ag}^{+}$substitution in the HA structure was discarded, since no changes were observed in the crystallographic planes of the HA and Ag, confirmed by the X-ray diffractogram.

According to Kim (1996), Kokubo (1996) and Liu (2013), the treatment of $\mathrm{Ti}$ with $\mathrm{NaOH}$ promotes a surface alteration of the sample, increasing its bioactivity and favoring HA nucleation, which does not occur in samples that did not undergo alkaline and thermal treatments ${ }^{25}$.

Figure 1c presents the spectrum obtained by EDX and confirms the presence of the element silver and hydroxyapatite constituents. The results of the EDX semi-quantitative microanalysis at point $\mathrm{A}$, indicates the presence of the chemical elements $\mathrm{O}$, $\mathrm{P}, \mathrm{Ca}$ and $\mathrm{Ag}$ (in weight \%): 37.7, 0.4, 0.8 and 5.5, respectively.

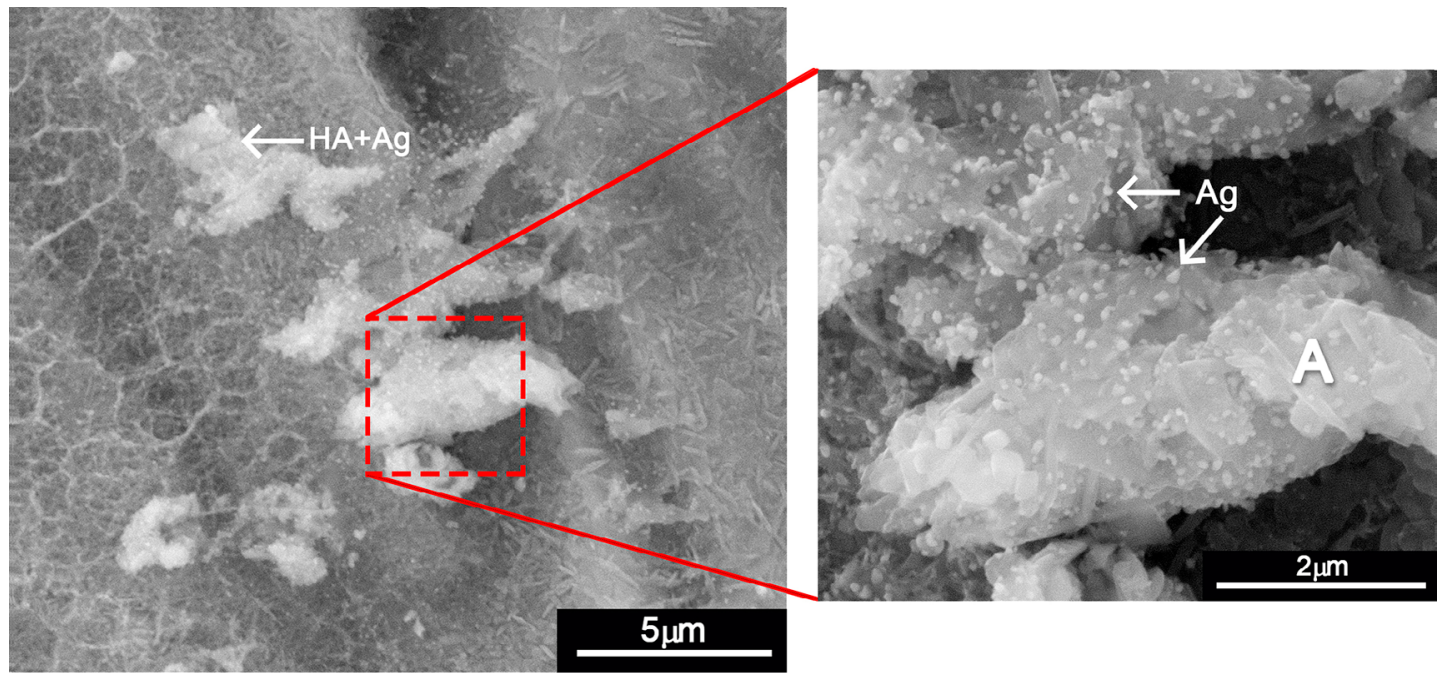

(a)

(b)

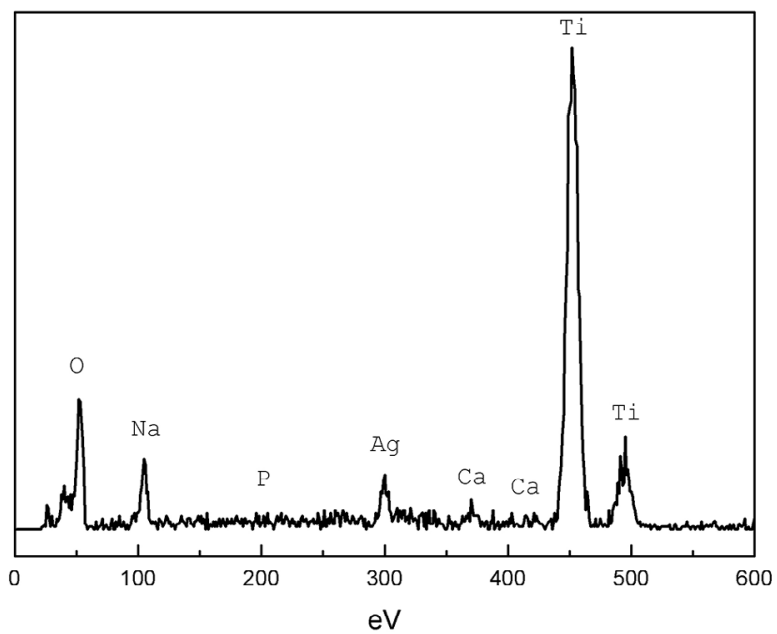

(c)

Figure 1. SEM micrograph for the sample $\mathrm{Ti}+\mathrm{HA}+\mathrm{AgNO}_{3}(\mathrm{a}, \mathrm{b})$ and (c) spectrum obtained in the microanalysis of EDX at point $\mathrm{A}$ 
The micrograph shown in Figure 2 correspond to the samples $\mathrm{Ti}+\mathrm{HA}+\mathrm{AgNO}_{3}+\mathrm{PCL}$ obtained by SEM along with the spectrum obtained by EDX microanalysis in the indicated regions. In Figure 2a, the micrograph showed silver and calcium particles sparsely deposited on the titanium surface, and some particles formed aggregates (region A). To verify the chemical elements present, EDX analyses were performed, as shown in Figures $2 \mathrm{~b}$.

The EDX spectrum undertaken in region A (Figure $2 b$ ) shows the presence of chemical elements typical of PCL ( $\mathrm{C}$ and $\mathrm{O}$ ), as well as $\mathrm{Ca}$ and $\mathrm{P}$, the main components of $\mathrm{HA}$, and $\mathrm{Ag}$ corresponding to the $\mathrm{AgNO}_{3}$ used in the doping of the coating. The presence of $\mathrm{Na}$ peaks in these spectra is due to the $\mathrm{NaOH}$ used in the alkaline treatment.

Micrographical analysis made by Ferreira (2018) allowed the observation of the presence of spherulites in the PCL film. In its EDX spectra, the main chemical elements found in the polymer (carbon and oxygen) were identified ${ }^{26}$.

Figure 3 shows the diffractograms of C.P. Ti and the coated $\mathrm{Ti}+\mathrm{HA}+\mathrm{AgNO}_{3}, \mathrm{Ti}+\mathrm{HA}+\mathrm{AgNO}_{3}+\mathrm{PCL}$. XRD analysis also confirmed the coating efficiency of $\mathrm{AgNO}_{3}$ and $\mathrm{AgNO}_{3}+\mathrm{PCL}$, corroborating the results obtained by SEM/EDX.

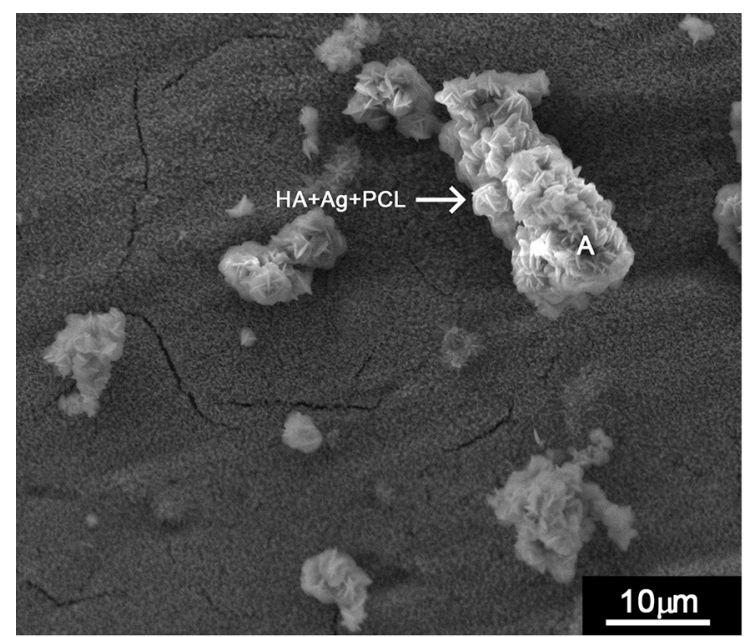

(a)
The characteristic peaks of the titanium $\alpha$-phase can be found in the diffractograms of C.P. Ti, $\mathrm{Ti}+\mathrm{HA}+\mathrm{AgNO}_{3}$, $\mathrm{Ti}+\mathrm{HA}+\mathrm{AgNO}_{3}+\mathrm{PCL}$, this $\alpha$-phase has a compact hexagonal structure. In addition, the diffractograms of $\mathrm{PCL}^{26}$ and $\mathrm{Ti}+\mathrm{HA}+\mathrm{AgNO}_{3}+\mathrm{PCL}$ indicate the presence of characteristic peaks of PCL. PCL presents an X-ray pattern with two intense reflection peaks at $2 \theta=21^{\circ}$ and $2 \theta=29^{\circ}$, reported by Wei et al. and Ferreira et al. ${ }^{26,27}$.

The presence of HA and Ag was observed in the diffractograms of the samples $\mathrm{Ti}+\mathrm{HA}+\mathrm{AgNO}_{3}$ and $\mathrm{Ti}+\mathrm{HA}+\mathrm{AgNO}_{3}+\mathrm{PCL}$. The distinctive peaks of HA are located at $2 \theta=33^{\circ}$ (JCPDS 09-0432) ${ }^{23}$, as observed by Chen et al. $(2006)^{28}$. Diffraction patterns obtained by Rakngarm et al. also showed HA peaks in a range of $2 \theta$ $=30-33^{\circ 29}$. They presented a significantly lower intensity in relation to the $\alpha$-phase peaks of C.P. Ti.

The peaks detected at $2 \theta=37.8^{\circ}, 43.8^{\circ}, 64.3^{\circ}, 77.5^{\circ}$ and $81.5^{\circ}$ refer to the crystallographic planes of Ag. As noted by Andrade et al. (2014), these correspond to the ( $\left.\begin{array}{lll}1 & 1 & 1\end{array}\right),\left(\begin{array}{lll}2 & 0 & 0\end{array}\right),\left(\begin{array}{lll}2 & 2 & 0\end{array}\right),\left(\begin{array}{lll}3 & 1 & 1\end{array}\right)$ and $\left(\begin{array}{lll}2 & 2 & 2\end{array}\right)$ planes of Ag face-centered cubic lattice (JCPS 04-0783) . $^{30}$

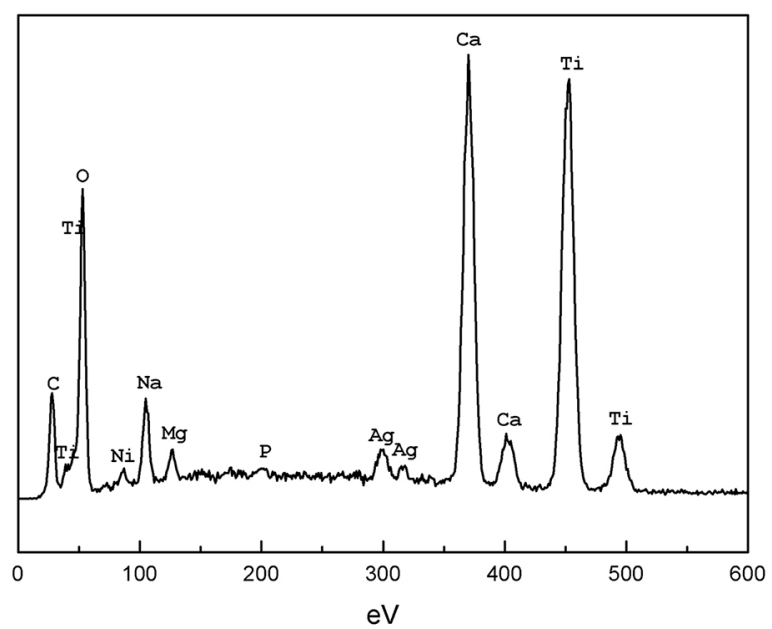

(b)

Figure 2. (a) Micrograph obtained by MEV for $\mathrm{Ti}+\mathrm{HA}+\mathrm{AgNO}_{3}+$ PCL. (b) Microanalysis obtained by EDX in region A.

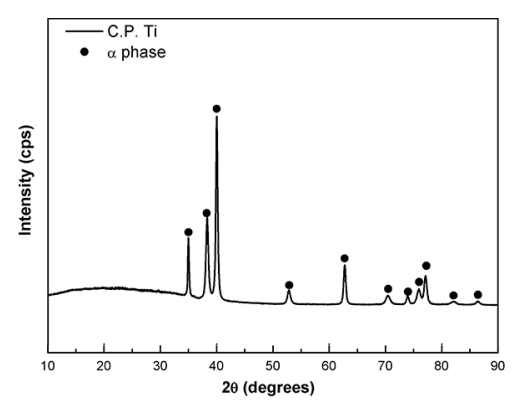

(a)

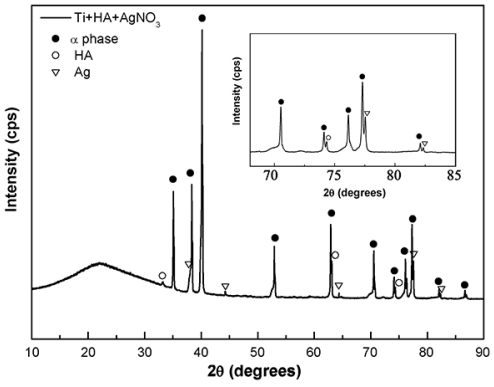

(b)

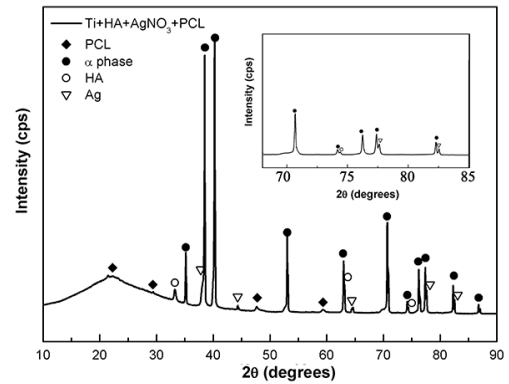

(c)

Figure 3. X-ray diffraction of C.P. Ti, $\mathrm{Ti}+\mathrm{HA}+\mathrm{AgNO}_{3}$ and $\mathrm{Ti}+\mathrm{HA}+\mathrm{AgNO}_{3}+\mathrm{PCL}$. 
The structure of hydroxyapatite allows easyisomorphic cationic and anionic substitutions. $\mathrm{Ca}^{2+}$ can be substituted by metallic cations, such as $\mathrm{Pb}^{2+}, \mathrm{Ag}^{+}, \mathrm{Cd}^{2+}, \mathrm{Cu}^{2+}, \mathrm{Zn}^{2+}, \mathrm{Sr}^{2+}, \mathrm{Co}^{2+}$, $\mathrm{Fe}^{2+}$. The phosphate groups can be substituted by carbonates and vanadatesand the hydroxyls by carbonates, fluorides and chlorides. These substitutions can alter crystallinity, the network parameter, crystal dimensions, surface texture, the stability and solubility of the structure of hydroxyapatite ${ }^{25,29,31}$.

Vieira (2013) observed the presence of the $\beta$-TCP phase in C.P. Ti samples with hydroxyapatite coating and doped with 20 and $100 \mathrm{ppm}$ of $\mathrm{AgNO}_{3}$. This phase is a result of the transformation in the hydroxyapatite structure by the substitution of $\mathrm{Ca}^{2+}$ ions (from the $\mathrm{HA}$ ) by $\mathrm{Ag}^{+}$ions (from the $\mathrm{AgNO}_{3}{ }^{23}$. However, Sousa and collaborators (2018) did not observe the presence of the $\beta$-TCP when the samples were doped with $10 \mathrm{ppm}$ of $\mathrm{AgNO}_{3}{ }^{32}$. As such, the choice of working with a concentration of $10 \mathrm{ppm}$ of $\mathrm{AgNO}_{3}$ was made.

$\beta-\mathrm{TCP}$ is a phase deficient in $\mathrm{Ca}^{2+}$ and one which can foster a structural disorganization in the HA, generating changes in properties such as network parameters, surface texture, crystallinity and material stability. In the samples $\mathrm{Ti}+\mathrm{HA}+\mathrm{AgNO}_{3}$ and $\mathrm{Ti}+\mathrm{HA}+\mathrm{AgNO}_{3}+\mathrm{PCL}$, it was observed that the presence of the $\beta$-TCP phase did not occur.

The use of spectroscopy in infrared allowed the monitoring and evaluation of the apatite coatings formed, with the identification of absorption bands stemming from the phosphate $\left(\mathrm{PO}_{4}{ }^{3-}\right)$, carbonate $\left(\mathrm{CO}_{3}{ }^{2-}\right)$ and hydroxyl $\left(\mathrm{OH}^{-}\right)$ groups $^{32,33}$. Figure 4 presents the results obtained by the FTIR of the C.P. Ti, C Ti+HA $+\mathrm{AgNO}_{3}, \mathrm{Ti}+\mathrm{HA}+\mathrm{AgNO}_{3}+\mathrm{PCL}$.

The absorption bands corresponding to the vibration of the phosphate and hydroxyl groups are directly linked to the presence of apatites. In the coated samples $\left(\mathrm{Ti}+\mathrm{HA}+\mathrm{AgNO}_{3}\right.$ and $\mathrm{Ti}+\mathrm{HA}+\mathrm{AgNO}_{3}+\mathrm{PCL}$ ), the band observed in the region between $3670-3570 \mathrm{~cm}^{-1}$ refers to the stretching of the $\mathrm{OH}^{-}$ group, while the peaks at 1196 and $1022 \mathrm{~cm}^{-1}$ indicate the stretching of the phosphate group $\left(\mathrm{PO}_{4}^{3-}\right)$ and, at $563 \mathrm{~cm}^{-1}$, its vibration.

The characterization of the type of hydroxyapatite was undertaken through the analysis of the vibrations of the $\mathrm{CO}_{3}^{2-}$ group. The peaks at 1514 and $880 \mathrm{~cm}^{-1}$ in $\mathrm{Ti}+\mathrm{HA}+\mathrm{AgNO}_{3}$ sample refer, respectively, to the stretching and the vibration of the type $\mathrm{ACO}_{3}^{2-}$, while the peak at $1465 \mathrm{~cm}^{-1}$ refers to the stretching of the $\mathrm{CO}_{3}^{2-}$.

The same could be observed in the sample containing polymeric coating, where the peaks observed at $1514 \mathrm{~cm}^{-1}$ and $1412 \mathrm{~cm}^{-1}$ refer to the stretching of the A and B type groups, respectively, characterizing the $\mathrm{AB}$ type apatite ${ }^{23}$. These results corroborate with the observed, confirming the results obtained through the SEM/EDX and XRD of the Ti+HA $+\mathrm{AgNO}_{3}$.

The peaks at 1031 and $955 \mathrm{~cm}^{-1}$ refer to the vibrations of the $\mathrm{PO}_{4}{ }^{3-}$ group, while the peak at $567 \mathrm{~cm}^{-1}$ refers to the stretching of the $\mathrm{PO}_{4}^{3-}$ group. The vibration of the $\mathrm{OH}^{-}$refers to the peak at $3662 \mathrm{~cm}^{-1}$. At $1621 \mathrm{~cm}^{-1}$, in $\mathrm{Ti}+\mathrm{HA}+\mathrm{AgNO}_{3}$ sample it refers to the deformation of the $\mathrm{H}_{2} \mathrm{O}$ group.

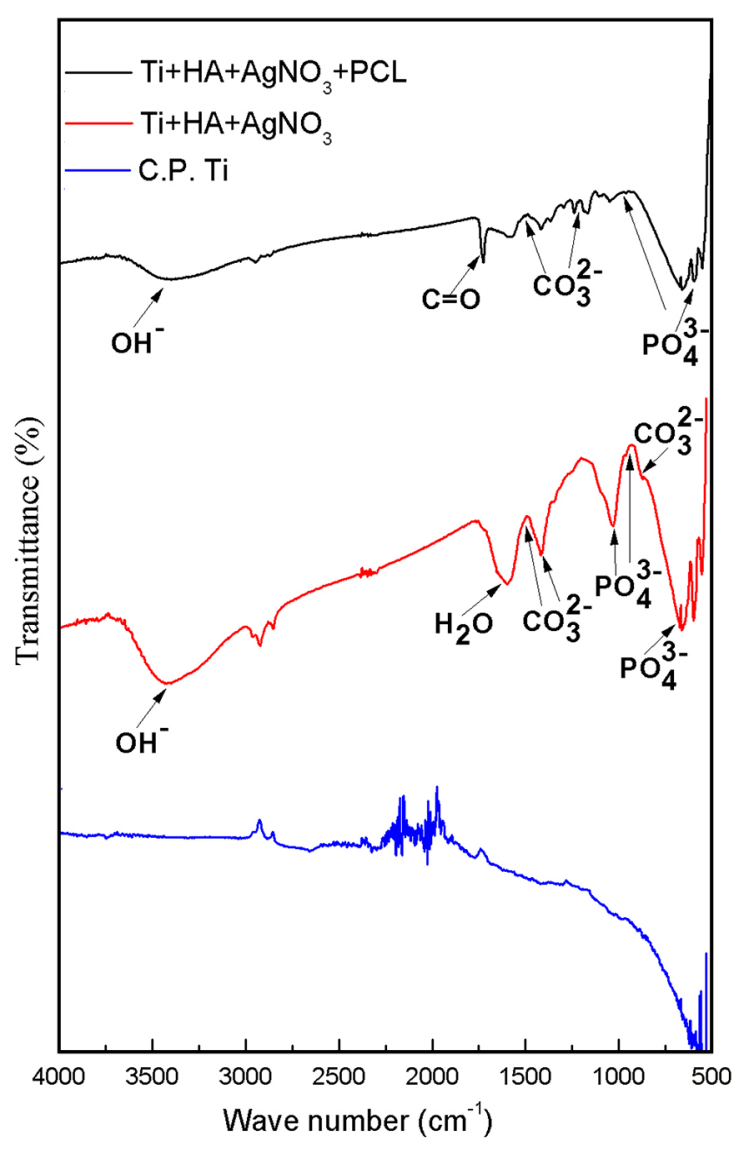

Figure 4. FTIR spectra of C.P. Ti, $\mathrm{Ti}+\mathrm{HA}+\mathrm{AgNO}_{3}$ and $\mathrm{Ti}+\mathrm{HA}$ $+\mathrm{AgNO}_{3}+\mathrm{PCL}$.

The absorption bands in the range of 2862 and $2942 \mathrm{~cm}^{-1}$ in $\mathrm{Ti}+\mathrm{HA}+\mathrm{AgNO}_{3}+\mathrm{PCL}$ sample derive from to the deformation of $\mathrm{CH}_{2}$ of the PCL, interconnected to the inorganic network. The band at $1726 \mathrm{~cm}^{-1}$ is attributed to the stretching vibration of the carbonyl groups $(\mathrm{C}=\mathrm{O})$ present in the PCL. Among the characteristic vibrations of the PCL, the absorption bands 1233, 1107 and $1042 \mathrm{~cm}^{-1}$ correspond to the asymmetric COC vibration ${ }^{26}$.

\subsection{Corrosion Testing}

Figure 5 shows the potentiodynamic polarization curves of C.P. Ti; $\mathrm{Ti}+\mathrm{HA}+\mathrm{AgNO}_{3}$ and $\mathrm{Ti}+\mathrm{HA}+\mathrm{AgNO}_{3}+\mathrm{PCL}$ and Table 1 shows the electrochemical parameters obtained from the polarization curves.

It was possible to observe that in the sample C.P. $\mathrm{Ti}$ there is a clear passive region, where the current density was practically constant, while the potential values suffer variations. This behavior indicates the formation of a passive film (possibly titanium oxide) on the surface of C.P. Ti (Ipass $\left.=1.116 \times 10^{-5} \mathrm{~A} / \mathrm{cm}^{2}\right)$, which breaks at a potential of around $1.35 \mathrm{~V}$. Afterwards, a layer of oxide was once again formed, indicating that the oxide adhered to the surface of the C.P. Ti and was stable there. Nevertheless, this behavior of passive film rupture did not occur in the sample $\mathrm{Ti}+\mathrm{HA}+\mathrm{AgNO}_{3}$. 


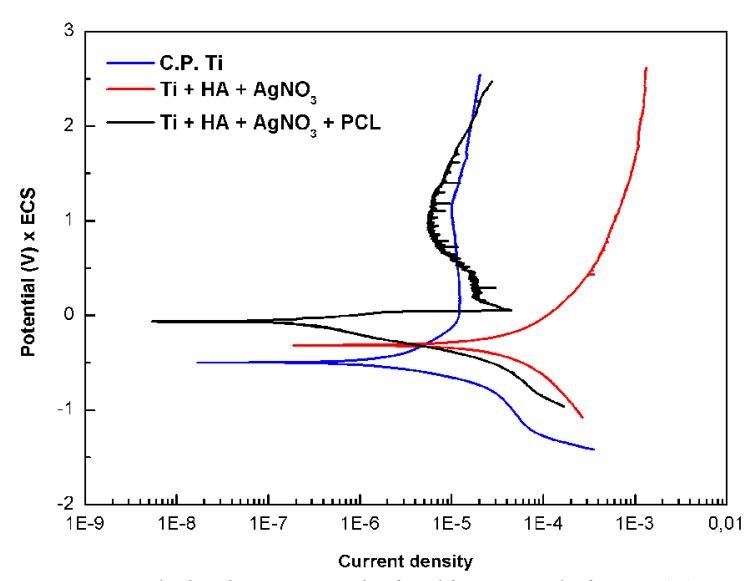

Figure 5. Polarization curves obtained in $\mathrm{SBF}$ solution, at $36.5^{\circ} \mathrm{C}$ and $\mathrm{pH}$ 7.4, for the samples: C.P. $\mathrm{Ti}, \mathrm{Ti}+\mathrm{HA}+\mathrm{AgNO}_{3}$ and $\mathrm{Ti}+$ $\mathrm{HA}+\mathrm{AgNO}_{3}+\mathrm{PCLw}$

Corrosion potential (Ecorr) of $\mathrm{Ti}+\mathrm{HA}+\mathrm{AgNO}_{3}(-0.2944$ $\mathrm{V})$ is similar to other coated conditions like Ti+PCL ${ }^{26}(-0.3061$ $\mathrm{V})$ and $\mathrm{Ti}+\mathrm{HA}^{32}(-0.321 \mathrm{~V})$, but higher than C.P. Ti (-0.4956 $\mathrm{V})$. This indicates that the coated are more stable and that the coatings slow the onset of the corrosive process ${ }^{34,35}$.

However, the corrosion potential of the $\mathrm{Ti}+\mathrm{HA}+\mathrm{AgNO}_{3}+\mathrm{PCL}$ was the largest $(-0.1239 \mathrm{~V})$ in relation to the other samples. This result was also observed by Catauro (2018), and it is due to the fact that the PCL is more inert and stable in an SBF medium when compared to the biomimetic coating (HA ${ }^{36}$.

Therefore, the use of PCL may protect the implant against the attack of body fluids and improve its biocompatibility 35,37 . This sample has a small passivation region (Ipass = $7.11 \times 10^{-5} \mathrm{~A} / \mathrm{cm}^{2}$ ), which breaks at a potential of around 1.3 $\mathrm{V}$, and it can be observed that repassivation does not occur, differently from C.P. Ti. This may be associated with the fact that the corrosion occurs preferentially in the coating and not on the surface of the C.P. Ti.

Oscillations in anodic current density on the polarization curve of the samples $\mathrm{Ti}+\mathrm{HA}+\mathrm{AgNO}_{3}+\mathrm{PCL}$ were also observed and are related to the consecutive formation and repassivation of micropits. These pits are identified as metastable, and grow and repassivate in a few seconds. This situation fosters the release of $\mathrm{AgNO}_{3}$, even in the presence of the PCL film.

It was observed by Sousa (2018) that samples containing chitosan $(\mathrm{Q})$ presented a similar behavior $\left(\mathrm{Ti}+\mathrm{HA}+\mathrm{AgNO}_{3}+\mathrm{Q}\right)$, but the rupture of the passive film occurred in superior potentials; thus, PCL will be more efficient than chitosan as medication releaser ${ }^{32}$.
The sample $\mathrm{Ti}+\mathrm{HA}+\mathrm{AgNO}_{3}$ exhibited the largest passive current density (Ipass $=1.12 \times 10^{-3} \mathrm{~A} / \mathrm{cm}^{2}$ ), as a result of the interaction of silver nitrate with hydroxyapatite, which alters the coating structure, reducing the speed of passive film formation. This fact is reinforced by the results obtained by Sousa (2018), in a Ti +HA sample, in a similar medium, which exhibited a lower passive current density (Ipass = $\left.5.472 \times 10^{-5} \mathrm{~A} / \mathrm{cm}^{2}\right)^{32}$.

\subsection{Bacterial Viability Trials}

Aiming to evaluate the bacterial viability and the formation of biofilms on the samples, a bacterial viability trial was conducted with Staphylococcus aureus, reported by Gristina and Costerton (1985), in infections associated with biomaterials ${ }^{38,39}$. The results obtained are shown in Figures 6 and 7. Additionaly, an analysis of bacteria in samples of $\mathrm{Ti}+\mathrm{HA}$ was performed, for comparative purposes.

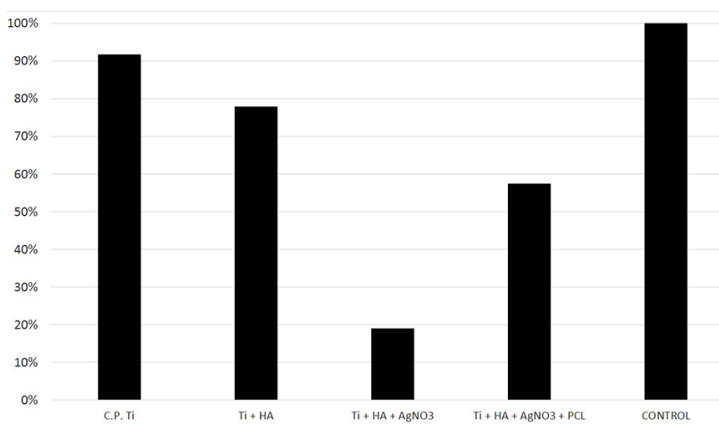

Figure 6. Bacterial viability trial for Staphylococcus aureus.

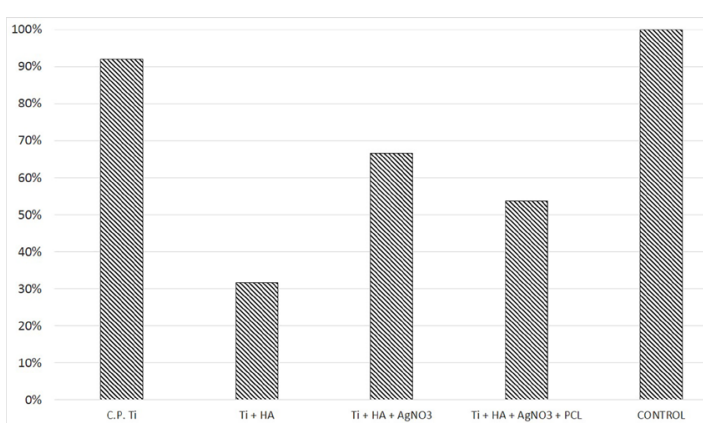

Figure 7. Biofilm formation trial for Staphylococcus aureus.

Figure 6 shows the bacterial viability in the supernatant after 24 hours of treatment with the samples. Analyzing the values obtained, it is possible to observe that the condition $\mathrm{Ti}$ presented a smaller reduction in the number of viable cells $(8 \%)$, followed by the condition Ti+HA $(22 \%)$.

Table 1. Electrochemical parameters obtained in $1.5 \mathrm{SBF}$ at 36.5 and $\mathrm{pH} 7.4$.

\begin{tabular}{|c|c|c|c|}
\hline Samples & Ecorr (V) & $\operatorname{Icorr}\left(\mathrm{A} / \mathrm{cm}^{2}\right)$ & $\operatorname{Ipass}\left(\mathrm{A} / \mathrm{cm}^{2}\right)$ \\
\hline C.P. Ti & -0.4956 & $1.801 \times 10^{-6}$ & $1.594 \times 10^{-5}$ \\
\hline $\mathrm{Ti}+\mathrm{HA}+\mathrm{AgNO}_{3}$ & -0.2944 & $4.700 \times 10^{-5}$ & $1.120 \times 10^{-3}$ \\
\hline $\mathrm{Ti}+\mathrm{HA}+\mathrm{AgNO}_{3}+\mathrm{PCL}$ & -0.1239 & $1.090 \times 10^{-6}$ & $7.110 \times 10^{-5}$ \\
\hline
\end{tabular}

Ecorr: corrosion potential; Icorr: corrosion current density; Ipass: passivation current density 
Xue and collaborators (2004) used a plasma spraying coating technique for coating the titanium with hydroxyapatite and, in addition, incorporated $\mathrm{Ag}^{+}$. By the diffusion halo trials and XRD they observed an excellent inhibiting capability in silver against gram-positive bacteria ${ }^{40,41}$.

The inhibitory capacity of silver, observed by the higher efficiency of the conditions doped with $\mathrm{AgNO}_{3}$, was characterized by this metal having a positive charge, which in contact with cell membranes that have negative charges, adhere to their surface, causing cell death and the total or partial elimination of bacteria ${ }^{41,42}$. For the samples $\mathrm{Ti}+\mathrm{HA}+\mathrm{AgNO}_{3}+\mathrm{PCL}$, a $42 \%$ decrease in the amount of live bacteria in the supernatant liquid was observed.

Without the polymer coating $\left(\mathrm{Ti}+\mathrm{HA}+\mathrm{AgNO}_{3}\right)$ the bacterial viability was reduced by $81 \%$, suggesting that the coating with PCL promotes a slower release of $\mathrm{AgNO}_{3}$. As expected, the presence of silver nitrate in $\mathrm{Ti}+\mathrm{HA}+\mathrm{AgNO}_{3}$ and $\mathrm{Ti}+\mathrm{HA}+\mathrm{AgNO}_{3}+\mathrm{PCL}$ significantly reduced the bacterial viability in the medium due to the release of silver ions. However, the PCL-coated sample showed a lower efficiency in 24 hours. The polarization curves for the condition $\mathrm{Ti}+\mathrm{HA}+\mathrm{AgNO}_{3}+\mathrm{PCL}$ presented a behavior which suggests that PCL promotes a release of silver ions in the culture medium, which can be considered favorable in cases of prolonged treatment.

Figure 7 presents the biofilm formation in the substrates, using the PE plate as a positive control for bacterial biofilm adhesion. In this case, PCL coating contributed to the reduction of biofilm formation compared to the sample $\mathrm{Ti}+\mathrm{HA}+\mathrm{AgNO}_{3}$. This can be attributed to the alteration of the topography of the surface after polymer coating, since the formation of biofilm is favored by roughness, which increases the retention of bacteria on the surface.

The first stage of biofilm formation corresponds to the interaction and adhesion between the cells and the substrate, with roughness and surface free energy being identified as the factors that exert the greatest influence in this process ${ }^{43,44}$. In the micrographs presented in Figures 1 and 2 it is possible to observe that titanium disk coated with PCL presents a smoother surface compared to the sample $\mathrm{Ti}+\mathrm{HA}+\mathrm{AgNO}_{3}$, making it difficult to retain bacteria.

The effect of surface hydrophilicity on the reduction of biofilm adhesion/formation can be observed by comparing the samples C.P. Ti and Ti+HA. After coating C.P. Ti with HA, phosphate and hydroxyl groups were introduced, which are highly hydrophilic, facilitating the formation of a water film on the surface of the substrate and consequently hindering the direct interaction between it and the bacterium.

In the present study, the antimicrobial effect of silver on the reduction of biofilm formation can be observed by comparing samples $\mathrm{Ti}+\mathrm{HA}$ and $\mathrm{Ti}+\mathrm{HA}+\mathrm{AgNO}_{3}$. Thus, the reduction of bacterial viability and biofilm formation in relation to the control indicates that the samples studied present a potential application for implants, due to the lower probability of rejection caused by the incidence of infection.

\section{Conclusions}

The microstructural characterization of $\mathrm{Ti}+\mathrm{HA}+\mathrm{AgNO}_{3}$ and $\mathrm{Ti}+\mathrm{HA}+\mathrm{AgNO}_{3}+\mathrm{PCL}$ proves the formation of a coating on the surface of the metallic substrate. The results from the XRD analysis confirm the typical peaks of $\alpha$ phase (compact hexagonal structure), hydroxyapatite, silver and PCL. The polarization curves reveal an improvement in the resistance to corrosion after doping with silver nitrate, and $\mathrm{Ti}+\mathrm{HA}+\mathrm{AgNO}_{3}+\mathrm{PCL}$ exhibited better resistance to corrosion. An $81 \%$ reduction in the amount of live bacteria in the supernatant liquid was observed in the sample $\mathrm{Ti}+\mathrm{HA}+\mathrm{AgNO}_{3}$, and a $42 \%$ reduction was observed in the sample $\mathrm{CP} \mathrm{Ti}+\mathrm{HA}+\mathrm{AgNO}_{3}+\mathrm{PCL}$. The bactericidal effect of the doping which was carried out is thus proved. Comparing the results obtained with and without coating, it is possible to note that the presence of $\mathrm{AgNO}_{3}$ was effective in reducing the amount of live bacteria present in the supernatant, as well the amount of live bacteria which adhered to the material's surface. Furthermore, the polymer coating was capable of releasing the bactericidal agent, as proved by the corrosion assay and bacterial culture assays, suggesting the extension of the effect of the bactericidal agent. Thus, the $\mathrm{Ti}+\mathrm{HA}+\mathrm{AgNO}_{3}+\mathrm{PCL}$ samples presented satisfactory results, such as corrosion resistance in bodily fluids, bone similarity (due to presence of HA), biocompatibility and bactericidal action, desirable characteristics for the application in medical implants.

\section{Acknowledgements}

The authors thank Brazilian research funding agencies FAPEMIG, Finep, CNPq and CAPES for financial support.

\section{References}

1. Kokubo T, Miyaji F, Kim HM, Nakamura T. Spontaneous formation of bonelike apatite layer on chemically treated titanium metals. Journal of the American Ceramic Society. 1996;79(4):1127-1129.

2. Kokubo T, Kim HM, Kawashita M. Novel bioactive materials with different mechanical properties. Biomaterials. 2003;24(13):2161-2175.

3. Kim HM, Miyaji F, Kokubo T, Nakamura T. Preparation of bioactive Ti and its alloys via simple chemical surface treatment. Journal of Biomedical Materials Research. 1996;32(3):409-417.

4. Fernandes DJ, Elias CN, Valiev RZ. Properties and performance of ultrafine grained titanium for biomedical applications. Materials Research. 2015;18(6):1163-1175.

5. Kulkarni M, Mazare A, Schmuk P, Iglic A. Biomaterial surface modification of titanium and titanium alloys for medical applications. Nanomedicine. 2014;111-136.

6. Geetha M, Singh AK, Asokamani R, Gogia AK. Ti based biomaterials, the ultimate choice for orthopaedic implants - A review. Progress in Materials Science. 2009;54(3):397-425 
7. Lu X, Leng Y. TEM study of calcium phosphate precipitation on bioactive titanium surfaces. Biomaterials. 2004;25(10):1779-1786.

8. Balazic M, Kopac J, Jackson MJ, Ahmed W. Review: titanium and titanium alloy applications in medicine. International Journal of Nano and Biomaterials. 2007;1(1):3.

9. Song HJ, Kim MK, Jung GC, Vang MS, Park YJ. The effects of spark anodizing treatment of pure titanium metals and titanium alloys on corrosion characteristics. Surface and Coatings Technology. 2007;201(21):8738-8745.

10. Mistry S, Kundu D, Datta S, Basu D, Soundrapandian C. Indigenous hydroxyapatite coated and bioactive glass coated titanium dental implant system - Fabrication and application in humans. Journal of Indian Society of Periodontology. 2011;15(3):215-220.

11. Kawachi EY, Bertran CA, Reis RR, Alves OL. Biocerâmicas: tendências e perspectivas de uma área interdisciplinar. Química Nova. 2000;23(4):518-522.

12. Raphel J, Holodniy M, Goodman SB, Heilshorn SC. Multifunctional coatings to simultaneously promote osseointegration and prevent infection of orthopaedic implants. Biomaterials. 2016;84:301-314.

13. Shoja M, Shameli K, Ahmad M, Zakaria Z. Preparation and characterization of poly ( $\varepsilon$ - Caprolactone)/TiO2 microcomposites. Digest Journal of Nanomaterials and Biostructures. 2015;10(2):471-477.

14. Shkarina S, Shkarin R, Weinhardt V, Melnik E, Vacun G, Kluger $\mathrm{P}$, et al. 3D biodegradable scaffolds of polycaprolactone with silicate-containing hydroxyapatite microparticles for bone tissue engineering: high-resolution tomography and in vitro study. Scientific Reports. 2018;8(1):8907.

15. Trentin DS, Giordani RB, Macedo AJ. Biofilmes bacterianos patogênicos: aspectos gerais, importância clínica e estratégias de combate1. Revista Liberato. 2013;14(22):213-236.

16. Smith CM, Roy TD, Bhalkikar A, Li B, Hickman JJ, Church KH. Engineering a titanium and polycaprolactone construct for a biocompatible interface between the body and artificial limb. Tissue Engineering: Part A. 2010;16(2):717-724.

17. Park JB, Bronzino JD. Biomaterials: Principles and Applications. Boca Raton: CRC Press; 2002.

18. ASTM International. ASTM F67-06 - Standard Specification for Unalloyed Titanium, for Surgical Implant Applications (UNS R50250, UNS R50400, UNS R50550, UNS R50700). West Conshohocken, USA: ASTM International; 2006.

19. International Organization for Standardization. ISO 23317 Implants for surgery - In vitro evaluation for apatite-forming ability of implant materials. Geneva: ISO; 2012.

20. Eraković S, Janković A, Veljović D, Palcevskis E, Mitrić M, Stevanović $\mathrm{T}$, et al. Corrosion stability and bioactivity in simulated body fluid of silver/hydroxyapatite and silver/hydroxyapatite/ lignin coatings on titanium obtained by electrophoretic deposition. The Journal of Physical Chemistry: B. 2013;117(6):1633-1643.

21. Ciobanu C, Massuyeau F, Constantin L, Predoi D. Structural and physical properties of antibacterial Ag-doped nanohydroxyapatite synthesized at $100^{\circ} \mathrm{C}$. Nanoscale Research Letters. 2011;6(1):613.
22. Stanić V, Dimitrijević S, Antić-Stanković J, Mitrić M, Jokić B, Plećaš I et al. Synthesis, characterization and antimicrobial activity of copper and zinc-doped hydroxyapatite nanopowders. Applied Surface Science. 2010;256(20):6083-6089.

23. Vieira JO. Recobrimento biomimético de HA dopado com " $A G$ ", sobre superficie de Ticp [dissertation]. São Carlos: University of São Paulo; 2013.

24. El-Nahrawy AM, Ali AI, Hammad ABA, Youssef AM. Influences of Ag-NPs doping chitosan/calcium silicate nanocomposites for optical and antibacterial activity. International Journal of Biological Macromolecules. 2016;93:267-275.

25. Liu X, Mou Y, Wu S, Man HC. Synthesis of silver-incorporated hydroxyapatite nanocomposites for antimicrobial implant coatings. Applied Surface Science. 2013;273:748-757.

26. Ferreira CC, Ricci VP, Sousa LL, Mariano NA, Campos MGN. Improvement of titanium corrosion resistence by coating with poly-caprolactone and poly-caprolactone/titanium dioxide: potencial application in heart valves. Materials Research. 2018;20(Suppl 1):126-133

27. Wei Z, Wang G, Wang P, Liu L, Qi M. Crystallization behavior of poly( $\varepsilon$-caprolactone)/TiO2 nanocomposites obtained by in situ polymerization. Polymer Engineering and Science. 2012;52(5):1047-1057.

28. Chen W, Liu Y, Courtney HS, Bettenga M, Agrawal CM, Bumgardner J, et al. In vitro anti-bacterial and biological properties of magnetron co-sputtered silver-containing hydroxyapatite coating. Biomaterials. 2006;27(32):5512-5517.

29. Rakngarm A, Miyashita Y, Mutoh Y. Formation of hydroxyapatite layer on bioactive $\mathrm{Ti}$ and $\mathrm{Ti}-6 \mathrm{Al}-4 \mathrm{~V}$ by simple chemical technique. Journal of Materials Science: Materials in Medicine. 2007;19(5):1953-1961.

30. Andrade P, Faria A, da Silva D, Bonacin J, Gonçalves M. Structural and morphological investigations of $\beta$-cyclodextrin-coated silver nanoparticles. Colloids and Surfaces B: Biointerfaces. 2014;118:289-297.

31. Mavropoulos E, Rossi AM, Costa AM, Perez CA, Moreira JC, Saldanha M. Studies on the mechanisms of lead immobilization by hydroxyapatite. Environmental Science and Technology. 2002;36(7):1625-1629.

32. Sousa LL, Ricci VP, Prado DG, Apolinario RC, Vercik LCO, Rigo ECS, et al. Titanium coating with hydroxyapatite and chitosan doped with silver nitrate. Materials Research. 2018;20(Suppl 2):863-868.

33. Azevedo AGS, Strecker K, Gorgulho HF. Efeito da temperatura em processos de sinterização de pós de hidroxiapatita. Cerâmica. 2015;61(357):52-59.

34. Mariano NA, Oliveira RG, Fernandes MA, Rigo ECS. Corrosion behavior of pure titanium in artificial saliva solution. Matéria (Rio de Janeiro). 2009;14(2):878-880.

35. Lam MT, Wu JC. Biomaterial applications in cardiovascular tissue repair and regeneration. Expert Review of Cardiovascular Therapy. 2012;10(8):1039-1049.

36. Catauro M, Bollino F, Papale F. Surface modifications of titanium implants by coating with bioactive and biocompatible poly ( $\varepsilon$-caprolactone)/SiO2 hybrids synthesized via sol-gel. Arabian Journal of Chemistry. 2018;11(7):1126-1133. 
37. Viteri VS, Fuentes E. Titanium and titanium alloys as biomaterials. In: Gegner J, editor. Tribology - Fundamentals and Advancements. London, UK: IntechOpen; 2013.

38. Gristina AG, Costerton JW. Bacterial adherence to biomaterials and tissue. The significance of its role in clinical sepsis. Journal of Bone and Joint Surgery. 1985;67(2):264-273.

39. Juan L, Zhimin Z, Anchun M, Lei L, Jingchao Z. Deposition of silver nanoparticles on titanium surface for antibacterial effect. International Journal of Nanomedicine. 2010;5:261-267.

40. Xue W, Tao S, Liu X, Zheng X, Ding C. In vivo evaluation of plasma sprayed hydroxyapatite coatings having different crystallinity. Biomaterials. 2004;25(3):415-421.
41. Fielding G, Roy M, Bandyopadhyay A, Bose S. Antibacterial and biological characteristics of silver containing and strontium doped plasma sprayed hydroxyapatite coatings. Acta Biomaterialia. 2012;8(8):3144-3152.

42. Lalueza P, Monzón M, Arruebo M, Santamaría J. Bactericidal effects of different silver-containing materials. Materials Research Bulletin. 2011;46(11):2070-2076.

43. Contreras LPC. Cerâmicas feldspáticas estratificadas e em blocos para sistema CAD/CAM: avaliação da topografia superficial, formação de biofilme e viabilidade celular [dissertation]. São José dos Campos: Paulista State University; 2017.

44. Teughels W, Van Assche N, Sliepen I, Quirynen M. Effect of material characteristics and/or surface topography on biofilm development. Clinical Oral Implants Research. 2006;17(Suppl 2):68-81. 